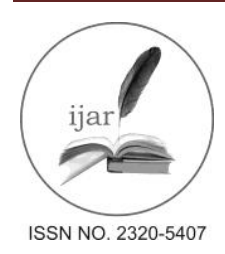

Journal homepage: http://www.journalijar.com
Journal DOI: $10.21474 /$ IJAR01

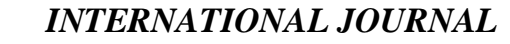

OF ADVANCED RESEARCH

RESEARCH ARTICLE.

\title{
APPLICATION OF POLITICAL RIGHTS OF WOMEN AND REPRESENTATIVENESS IN PARLIAMENT
}

Nur Asikin, Aminudin Ilmar, Alma Manuputty, and Nurfaidah Said.

\section{Manuscript Info}

Manuscript History:

Received: 18 April 2016

Final Accepted: 19 May 2016

Published Online: June 2016

Key words:

political rights and representation of women

*Corresponding Author

Nur Asikin.

\begin{abstract}
Political rights and representation of women in the implementation of the political moment in Indonesia is not a little problem that occurred in Indonesia. First Indonesian Women's Congress in 1928 was a milestone for Indonesian women in their efforts to expand the role of the public, particularly in politics. In this forum, the women's organizations of different ethnic groups, religions and languages united. The emergence and development of these organizations play an important role in improving women, such as improving management skills, broaden your horizons, and develop the network. Organizations and movements increased the bargaining position of women, as demonstrated by the frequency of the leaders of these organizations in various development activities, carried out by communities, governments and other institutions. In the political context, organizations that train and increase the capacity of women's self is an effective network for recruiting legislative candidates. Additionally in the period of independence, the people accept and respect women freedom fighters who had a role on the battlefield, in education, in medicine, and in the management of logistics. This opportunity facilitated women to fight for the issues that are relevant to their interests or that is happening around them, in addition to political issues.
\end{abstract}

Copy Right, IJAR, 2016.. All rights reserved.

\section{A. Introduction}

History of women's representation in parliament Indonesia is a long process, about the struggle of women in the public sphere. First Indonesian Women's Congress, in 1928, which is to raise awareness and increase the sense of nationalism among women is a milestone, because it plays a role in increasing the opportunities for Indonesian women to participate in development, including in politics. In the first general election in 1955, 6.5 percent of MPs are women. Then, the Indonesian women's representation in parliament have ups and downs, and reached the highest rate at 13.0 percent in 1987. Today, women constituted 8.8 per cent of all elected 
representatives. The lack of women's representation in parliament due to a series of obstacles that limit their advancement.

In a normal political conditions, elections in Indonesia are held every five years. The first general election was held ten years after Indonesia achieved independence from colonial rule in 1955, under the Soekarno government. The second election was not held because the Constituent Assembly charged with amending the 1945 Constitution can not complete the task, so in 1959 the government issued a decree to return to the 1945 Constitution Indonesia is the guided democracy. In 1965 there was a shift from the Old Order to the New Order, without an election. After this transition, general elections were held successively in 1971, 1977, 1982, 1987, 1992, and 1997. All these elections took place during the New Order regime under Soeharto administration. The transition from the Soeharto government to B.J. Habibie after the 1997 election was followed by an accelerated election in 1999. At this time, the people led by students demanding reform, which played a major role in ushering in a new national leader, Abdurrahman Wahid, the leader of a new party. Changes in the way of organizing the elections, with the number of political parties is quite large under the Old Order, into three parties under the New Order, then to 48 parties in the reform era, resulted in significant changes in the pattern of women's representation in various state institutions, in particular House of Representatives (DPR), at various levels of administration. Although nationwide, since the 1955 election, women have been represented in the House of Representatives and in the People's Consultative Assembly (MPR), the percentage of their participation has varied.

During the first election, in 1955, some of the women candidates are members of women's organizations affiliated to the party. In the next election, there is a tendency for legislative candidates come from the leadership of women's organizations under the auspices of the party or affiliated with any party.

In a state that a patriarchal value system, such as Indonesia, the opportunity for women to become politicians are limited because of the public perception regarding the division of roles between men and women, who tend to be biased towards restricting a woman's role in domestic affairs. However, during the struggle for independence, the need for fighters, both male and female, to open up opportunities for women to become involved outside the domestic sphere with the responsibility of managing the household. Society accepts and respects women freedom fighters who had a role on the battlefield, in education, in medicine, and in the management of logistics. This opportunity facilitated women's fight for the issues that relate to their interests or that is happening around them, in addition to political issues. In the 1955 election, during the Old Order, the number of women in Parliament reached 17 people, four of them from the organization Gerwani and five of NU's.

\section{B. Problems}

"How Implementation Of Women's Political Rights In Indonesia And They Representativeness In Parliament?"

\section{Discussion}

\section{Representation of Women}

According to Joni Lovenduski that there are three mechanisms that can be taken to improve the representation of women in parliament: one, the rhetoric (Rhetoric Strategies) to accommodate women in the Platform of political parties and campaigns: the second, the strategy of positive discrimination or quotas (Strategies of positive discrimination the quota) through the 
provision of reserved seats for women as candidates for the third legislative affirmative action strategies such as determining how the target number of women as candidates. ${ }^{1}$

Joni Lavenduski outlook calls for two forms of representation of women in parliament, which is a political party in the campaign and through the parliamentary quota. Two things are related to the author's intended Lovenduski view of the representation quotas through a process (campaign) and parliamentary representation through quotas. In connection with the view Joni Lavenduski as Miriam Budiardjo that today's political representation is a system of representation which is considered the most reasonable. ${ }^{2}$

For comparison some country representation system, namely: in the State of India by lifting some representatives of the Anglo-Indian groups (the lower house), class culture, literature, and social workers (the upper house). Countries Pakistan raised some groups among women, groups of former governors, ministers, among cultures, science class, profession lawyer. Countries Ireland lifted functional group as a senate under Act 1937 Constitution of the Republic France-IV in 1946 which established special assembly outside the legislature, the economic council is entitled discussing economic issues the state, although not have the authority to take decisions, just leave advice to the legislature. In Italy in 1926 the state representatives is based on economic class, then in the form of 22 "corporation", each representing industries such as the textile industry. it departs from the principle of "Function representation". While in Indonesia in 1971 the principle of functional representation is also known in addition to the principle of political representation, which is in addition to the political parties also included in the selection of functional groups.

Similarly to what happened in Papua that is known as the Papuan People's Assembly (MRP) on the basis of Article 19 of Law No. 21 of 2001 on Special Autonomy for Papua Province that "Papua People's Assembly (MRP) consisting of the native people of Papua consisting of representatives of indigenous, religious representatives, and representatives of women whose numbers each third of the total members MRP.

Efforts to achieve gender equality to allow representation between women and men in politics, it is in conformity with the constitution to give birth representatives without any distinction of sex, race, religion, and ethnicity. Decision-making is not only dominated by a particular group, but there is equality in representation.

However, the representation with the consideration of sex, race, religion, not only for consideration of representation by groups and parties only. Nevertheless, it should be considered their respective competences. For example in representation in parliament then surely play an important role in allowing a strengthening of the parliamentary candidate is a political party that does have the main task of the cadres.

Consideration of the representation of women in the implementation of the political moment in Indonesia is based on a consideration of the problem of women who did little happening in Indonesia, it is thus in order to obtain an answer or a solution of women's problems, at least not done by women anyway. Likewise, the issue of children and injustice against women, either within the company or in the parliament.

1 Joni Lovenduski, Introduction: the Dynamic of gender and party" in gender and parti politics Joni Lovenduski and pippa Noris (eds.) 8 (London Thousan oaks, New delhiL sage publications, 1993

2 Miriam Budiarjo 2008. Dasar-dasar ilmu Politik ed-refis. PT gramedia Pustaka Utama. Jakarta Hal : 176 
To realize the substantive justice in the process of representation of women, it is necessary to an impartial justice in one particular group, but the equality of all people in the political process.

According to the author, that the understanding of democracy in Indonesia is the space of political rights of individuals and groups, are living adequate legal arrangement to be used as a reference / guide in politics.

In some people's concept of representation is at least the idea of representation and representation of reality. Representatives of ideas is the representative and the represented are not necessarily the same type. However, the trust (confidence) given to the representative for the representation of women in parliament with a quota of $30 \%$ in the legislature. The pattern uses the principle of representation of reality, that women represent women, however women voters could have been the man with the argument that men can only choose women because of its importance entrusted to a woman.

According to Investigators that affirmative action in fulfillment of the rights of women in the Legislature is basically composed of two approaches to the process approach and approach the goal, the process approach is the provision of a minimum quota to women in the nomination process with the necessity Reviews their $30 \%$ quota for women as legislative candidates. While the approach of the purpose is to give $30 \%$ quota for women in legislative bodies.

On approach it as the respective rights of women assuming give to represent the aspirations of women in the Legislature. if, then his approach to the process, either individually as women will compete with other women and with men, whereas if more women approach the goal in the competition yourself with other women.

On approach the goal, basically the sound of men do not Affect the voice and sound while the female does not Affect a man's voice. Unless the settings, the sound of the rest of the $30 \%$ will be given to the party to be Able to serve as the voice of accumulation party.

The representation of women do with a minimum quota of $30 \%$ women in legislative bodies at all levels of legislative reality is $30 \%$ of the members of Parliament, $30 \%$ of members of the Provincial Parliament, and $30 \%$ of the level Regency / City.

Setting the minimum quota of $30 \%$ at all levels between individuals Fitness competition is female. This means that anyone majority vote of women throughout Indonesia will sit up split out $30 \%$, so that competitive sound is the voice of women throughout Indonesia.

When, the voice of women has Reached $30 \%$, then the next vote is going to Compete with male voice based on the provisions of applicable law. So if it is based on provisions of the law, it can only women will be higher then the chair so women will Increase by more than $30 \%$.

On the idea of women's representation is basically giving political rights of women in the management of the state. So associated with women's issues will be resolved by the women Themselves. At least the argument that women's issues will be resolved by the women Themselves. While the men will take care of the issue of the state in general, can even help women, then it is a part rather than participation.

\section{Aspiration}

Throughout the various movements in Indonesia and aspirations of women in some countries in the realization of women's representation in the legislature, is a female aspiration that runs quite long. This means that women's interests are not instant for entry into parliament simply because a "jealousy", but nevertheless based on some good approach of the philosophical, juridical, political and sociological. 
The quantity indeed have the power to give women political rights set forth in the provisions of the laws. Likewise qualitatively, that not a few women who were involved in politics and was able to gie best services for a change in the state and nation. The women's capabilities not only at the local level Regency / City but also at provincial and central levels.

Activity elections (general election) is also a means of distribution rights of citizens very principle. Therefore, in the framework of the implementation of the rights of citizens is imperative for the government to guarantee implementation of the elections in accordance with constitutional predetermined schedule. His relationship with the inspirational as RH Taylor's ${ }^{3}$ view, that: "A democratic election requires a number of requirements, namely: a) the recognition of universal suffrage; b) the discretion to establish shelters for plurality voting public aspirations; c) the existence of political recruitment mechanism for prospective representatives were open; d) the lack of freedom for voters to discuss and determine the choice; e) the flexibility for parties and candidates to compete healthily; f) the vote count conducted honestly; g) neutrality of the bureaucracy; and, h) the existence of an independent electoral management bodies.

Representation of women, based on the constitution and doctrine, as a consequence that Indonesia is a country of law, that any form of regulation is based on a provision of the applicable law.

\section{Participation}

The issue of women's participation is still very inadequate institutional involvement in women. Yet some women pressure groups requires Reviews their 30\% representation of women in the Legislature. however, even if the Act No. 8 In 2012 set up at least 30\% of women in the list of candidates for members of the Legislature.

This means that women's participation in formal institutions is still very far from complete, it can happen because of laws hasty and capricious. Thus, even if she championed but Also the participation of women is Necessary to Be Able to encourage other women to his involvement in the Legislature. It is as Disclosed by Hemas ${ }^{4}$ "It turns out that the law has not been Able to give effect to women. Political participation of women in formal political institutions is far from ideal,"

Hence for affirmative action for women in the Legislature Fought through representation candidates are not Able to encourage women to sit Legislature instituted as expected. Similarly, affirmative action should have been given the specialization for women to $30 \%$ into the Legislature.

The issue of affirmative action to do with women's participation is a variety of challenges that have to be made concern: first, the policies that government policies have the power to provide $30 \%$ quota for women in parliament by providing space Participation of women to be Able to access information on the levels of the government related to society. Second, the commitment of the commitment of women to Participate in government is very important. Because the issue of women's representation is a matter of the will of who was born and her desire for any problems that Arise in society. So by giving a quota of $30 \%$ women in parliament, it does need Reviews their commitment.

3 RH Taylor, "Election and Politics in Southeast Asia," dalam RH Taylor, 1996. ed, The Politics of election in Southeast Asia, Canbridge: Woodrow Wilson Center Press and Canbrige University Press, Hal $: 2$.

${ }^{4}$ Wakil Ketua DPD GKR Hemas saat seminar nasional 'Peran Legislator Perempuan Dalam Sistem Parlemen di Indonesia dan Jerman' di Hotel Sari Pan Pacific, Jakarta, Selasa (17/2). 
For women without Reviews their commitment, then people tend to have no confidence in women. Third, the quality that besides the force of law, the regulation of the power in the realization of women's representation in the Legislature. So the most important thing is Also must possess the quality of the women in the nomination process. For positions legislative competence is Necessary Because The position with regard to the design function of the laws, the supervisory function, budgeting functions, and aspiration functions.

Relating to the quality of legislative candidates from among the group of women there are some groups that should participate in the development of quality, namely : women's groups, political parties and governments. The three groups have an important role in encouraging women's quality to be able to expand the mandate of members of the legislature . Relating with their $30 \%$ quota for women then the group should provide reinforcement of quality to cause the minimum quota of women in parliament is affirmative action quotas is definitely women enter parliament.

\section{Closing}

Until now, the parliamentary system prevailing in Indonesia is a proportional electoral system. However, many people argue that proportional representation could be the best opportunity to increase of representation, as women can be asked to Participate in the election through the use of lists of candidates. If women are well represented in positions that can be selected in this list, they stand a good chance of being Elected. Therefore, the revision of the electoral system can have a good influence members for election of women to parliament in the future .

\section{References}

Joni Lovenduski, Introduction: the Dynamic of gender and party" in gender and parti politics Joni Lovenduski and pippa Noris (eds.) 8 (London Thousan oaks, New delhiL sage publications, 1993

Miriam Budiarjo 2008. Dasar-dasar ilmu Politik ed-refis. PT gramedia Pustaka Utama. Jakarta

RH Taylor, "Election and Politics in Southeast Asia," dalam RH Taylor, 1996. ed, The Politics of election in Southeast Asia, Canbridge: Woodrow Wilson Center Press and Canbrige University Press

Wakil Ketua DPD GKR Hemas seminar nasional 'Peran Legislator Perempuan Dalam Sistem Parlemen di Indonesia dan Jerman’ di Hotel Sari Pan Pacific, Jakarta, Selasa (17/2).

Khofifah Indar Parawansa, Hambatan terhadap Partisipasi Politik Perempuan di Indonesia, Studi Kasus: Hambatan terhadap Partisipasi Politik Perempuan di Indonesia, web cs .indonesia.khofifah 